\title{
The Thirty Years War
}

Lind, Gunner; Haude, Sigrun; Kampmann, Christoph; Rizzo, Mario; Tischer, Anuschka

Published in:

German History

DOI:

10.1093/gerhis/ghx121

Publication date:

2018

Document version

Publisher's PDF, also known as Version of record

Citation for published version (APA):

Lind, G., Haude, S., Kampmann, C., Rizzo, M., \& Tischer, A. (2018). The Thirty Years War. German History, 36(2), 252-270. https://doi.org/10.1093/gerhis/ghx121 


\section{FORUM}

\section{The Thirty Years War}

The Thirty Years War (1618-1648) remains a defining event in early modern European history generally, and in German history more particularly. It is still widely considered to mark major political, religious, military and socio-economic transitions. For Europe, the foremost of these is the alleged shift from an 'age of religious wars', supposedly characterizing the period since the Reformation, to an era defined more by dynasticism and disputes over territory and status. Warfare was supposedly 'tamed' by more centralized states which now maintained permanent 'standing armies', rather than relying on 'rootless mercenaries' as before 1648. Several decades of research have undermined the characterization of the period 1648-1789 as an 'age of absolutism', but political power is still widely seen as shifting from aristocrats and local elites to become more concentrated in central, monarchical institutions. These institutions provided greater internal stability for states, and, in turn, the increased domestic political strength supported a more stable international order. German history is widely regarded as partially following this broader European transition wrought by the war. Though the exact scale of destruction remains controversial, all are agreed that the war severely disrupted the previous social and political order within the Holy Roman Empire, terminating some trends and radically redirecting others. There is now considerable evidence that the Empire was not reduced to a meaningless shell, as older accounts maintained, but instead remained flexible and even capable of further political development. Nonetheless, the conventional idea that power shifted irrevocably from Imperial institutions to the princely territories continues to shape research, not just into political affairs, but also on social, cultural and economic history.

In 1998, the 350th anniversary of the Peace of Westphalia was marked by a number of major public exhibitions and important scholarly publications which broadly presented the settlement in a positive light, whilst nonetheless relativizing some of the more extravagant claims in the older literature for its status as a decisive 'turning point' in world history. It is perhaps always easier to commemorate a peace than to mark the anniversary of a war's outbreak. While the Westphalian peace is no longer regarded by the broader German public as a national humiliation, the Thirty Years War that it settled is still remembered as a catastrophe, and it is likely that this impression will be reinforced during the 400th anniversary of the conflict's conventionally accepted starting point in the Defenestration of Prague, which will be marked in 2018. The parallel centenary of the First World War, which has continued since 2014, has certainly generated a fruitful debate on how that conflict should be interpreted, even if some of the new insights have not yet altered the media's representation of the war. The 2018 anniversary thus offers a suitable moment to take stock of the current state of scholarship on the Thirty Years War and to consider where future work might lead. To this end, the editors of this Forum invited Sigrun Haude (Cincinnati), Christoph 
Kampmann (Marburg), Gunner Lind (Copenhagen), Mario Rizzo (Pavia) and Anuschka Tischer (Würzburg) to reflect on four enduring issues associated with the war, and to consider the historical methodologies underpinning the more recent research. The Forum was jointly convened by Peter H. Wilson (Oxford) and David Parrott (Oxford).

\section{Was the Thirty Years War inevitable? Or at least, was a conflict of this scale and duration inevitable? What do the responses to this issue tell us about the current thinking on the relative balance between agency and structure in historical research?}

Tischer: I don't think that any war has ever been inevitable. The outbreak of war is caused by human activity, and the outbreak of the Thirty Years War was caused by notable individuals, i.e. the Bohemian rebel leaders on the one side, and the future Emperor Ferdinand II and his counsellors and supporters on the other. In the decade before 1618, many people were well aware of tensions and some leading figures tried to alleviate the situation. For example, the electors of Saxony, Christian II, who died in 1611, and his son and successor, John George, refused to take part in the Protestant Union or in any revolt, although they were traditional leaders of the German Protestants. At the Habsburg court, Cardinal Khlesl, a representative of the Counter-Reformation in Austria, worked for a compromise with the Protestants in the Empire. Moreover, neither Maximilian of Bavaria's use of force against the Imperial city of Donauwörth in 1607 nor the Jülich-Cleves succession crises between 1609 and 1614 led directly to war in 1618. Once the Thirty Years War broke out, there were not just three decades of military action and confrontation, but also numerous negotiations. In my view, the war's outbreak owed much to there being the wrong men in the wrong place at the wrong time: men who insisted stubbornly on what they regarded as their right and who were ready to fight for it; moreover, men whose convictions were mixed with ambition, such as Frederick $\mathrm{V}$ of the Palatinate, who tried to become king of Bohemia.

Admittedly, the complex political and legal situation in the Holy Roman Empire and in Europe offered potential enough for war. The Emperor sought power but had limited means of enforcement, whereas the estates who counterbalanced him were not homogenous and struggled with each other. The attempt to resolve religious conflict in the Peace of Augsburg (1555) had created several legal ambiguities, notably the ecclesiastical reservation intended by the Habsburgs to preserve the lands of the Imperial church for Catholics. Meanwhile, the Habsburgs were widely regarded as a threat, not only in the Empire, but across Europe. There were other dynastic rivalries, as well as more generally unfavourable conditions like the Little Ice Age which intensified economic difficulties. Many people obviously anticipated a confrontation, an expectation fuelled by the growing print media. Thus, a war could have broken out sooner or later, even if there had been a smooth solution to the problems in Bohemia.

Those who were responsible for the war's outbreak all had experience of war and politics. Ferdinand II clearly spelt out in his published declaration against the Bohemian rebels that death, ruin and atrocities would follow from armed conflict. The opposing parties obviously accepted these dire consequences. 
None of them, of course, had any idea just how bad things would be or what kind of vicious circle of violence they had initiated. When the various latent conflicts burst out, it became extremely difficult to return to peace. Even today, historians struggle to disentangle the numerous conflicts in this war and the multitude of elements which determined them. Thus, it is no surprise that the men who began the war did not have an overview of what might happen. Nevertheless, they were responsible for the war, even though I would affirm that it was a confused situation which combined with a widespread and socially accepted readiness to use violence that prompted the outbreak.

Haude: While earlier scholarship drew a straight line from 1555 to 1618 and argued that the Peace of Augsburg inevitably set up the later conflict, historians now widely challenge this interpretation, and for good reasons. The former approach had emphasized the shortcomings of the 1555 settlement, which, it was argued, heightened the Holy Roman Empire's fragmentation by adding religious to political divisions, whereas historians more recently have drawn attention to the impressive longevity of the treaty and to concerted efforts on both sides to make the peace work. In this important shift of historical perspective, which has much to do with changes in political climates, the Holy Roman Empire morphed from a fragmented, ungovernable entity into an impressive federation of states ahead of its time. This reassessment represents more than a change in perspective - that is, looking at the glass as half full rather than half empty - because it pays attention to forces that have largely been overlooked or disregarded. In this argumentation, the widespread and shared interest among the Imperial estates in upholding the constitution, as it was interpreted in Augsburg, holds centre stage. In the decades after 1555, the treaty served more as plumb line than as point of contention for the estates, and continued to do so for the Protestant Union in 1608 and the Catholic League in 1609, all the way up to the Peace of Westphalia. As a rule, the constituent parts of the Empire preferred peace over war.

With regard to current thinking on the relative balance of agency and structure, historians are more divided, although many foreground structural factors over human agency by arguing that realities of military operations outweighed whatever brilliance might be possessed by strategic commanders.

Structural issues also influenced the war's scale and duration. Both Denmark and Sweden lacked the resources to end the conflict once they had intervened. Moreover, issues over interpretation of the constitution continued to be proffered as reasons for going to war. Even though in the interplay of structures and human agency the former may win the day, the latter ought not to be discounted. Personal factors could trump structures if conditions were right (or wrong, depending on one's point of view), as they were before the outbreak of war, when the emperors became too weak to govern effectively. In his German Histories in the Age of Reformations, 1400-1650 (2009), Thomas A. Brady, Jr. showed the interaction of structure and personalities. Importantly, giving political, constitutional and operational structures too much or exclusive play also runs the risk of viewing the conflict solely in terms of its major leaders and forces. More recent studies on the war's social dimensions try to move beyond operational and strategic thinking towards the role of the populace during the conflict. Rather than disregarding large segments of the population or viewing the people merely as victims of larger forces and (ruthless or hapless) commanders, these studies highlight people's agency as they responded to the war's challenges. 
Kampmann: At no time was the path into war irreversible, nor was escalation inevitable once the conflict had begun. Before 1618 almost all the major political and confessional actors tried to avoid war, and thereafter no party aimed at its enemy's total destruction or to impose a confessional absolutism (or indeed any other values). On the contrary, all belligerents remained capable of political dialogue.

Therefore, modernizing phrases like confessional 'fundamentalism' are unsuitable to define the positions of the protagonists during the war. Nothing demonstrates this more clearly than the fact that no party was prepared to go to war or even felt prepared for war. War and its escalation were seen as dangerous by all participants. For example, at the beginning of the conflict both the Emperor and his Bohemian adversaries knew very well that they did not have the necessary means to make war.

Of course, this raises the question of why the war broke out and why it escalated repeatedly. The answer has much to do with the general attitude towards war, which was seen as a possibility and an option by all parties. All felt entitled to make war, not only against foreign sovereigns, but also (within the Empire) against other Imperial estates. The latter can be seen as the worst consequence of the growing confessional confrontation and constitutional decay of the Empire around 1600. In my view, the crucial point is that there was widespread fear that the enemy was only waiting for the right moment to take military action. Therefore, a key phrase in all internal discussions was praevenire, to forestall. We must defend ourselves before it is too late - this attitude characterized the position of the Bohemian 'rebels' in May 1618, as well as the Palatinate in July/ August 1619, and the Emperor in 1624/25 and 1629. As the war developed, this attitude (now expressed as 'react now to prevent future evils') shaped policy towards peace as well. There was widespread concern that a peace based on significant concessions by one's own side might be regarded as humiliating and a severe blow to one's own reputation, and the longer the war lasted the more firmly this concern became established. Only an 'acceptable' peace could ensure a safe postwar position.

To my mind, the change of attitude in recent historiography towards the inevitability of the war has little to do with thinking on the balance between agency and structure. The older historiography stressed the importance of individual military and political decisions - in terms of individual people ('great men') making history. But exactly this older (German) historiography considered the war a necessary outcome of the long-lasting fragmentation and decay of the 'German' Empire. Recent research has attached greater importance to the structural conditions in which individual decisions were taken. Yet even though a structuralist approach underpins this research, the war's outbreak and escalation are not seen as inevitable.

Lind: Nothing is inevitable until it happens. We can imagine a landscape of risk like the insurance companies do, composed of a range of possibilities with a probability assigned to each. But it is even more complex when discussing history. Possibilities and probabilities change with our viewpoint in time. Do we look at the Thirty Years War from one, five, ten or fifty years before its outbreak? The outlook changes as we shift our imagined vantage point, even if we restrict ourselves to a reasonable human timescale. That said, we can look at the tensions nudging people towards war. They include hostility between the confessions, rival interests concerning the German constitution, and relations to the mighty House of Austria, all viewed through the lenses of pride, greed 
and fear. Many greater and lesser wars arose from these tensions over a long period, both before and after the Thirty Years War. It would have been a safe prophecy in 1610 or 1600 , or even quite a bit further back, that yet another big war was not very far away and would connect two or more of these elements.

I am less sure that a conflict of this extraordinary scale and duration was likely. It was even unlikely far into the war. From 1621 until 1630 the Protestant side had to be reconstructed time and again against the odds. A little more patience and circumspection among their adversaries and the war could have been wound down, rather than repeatedly reignited. 'Has he [the Emperor] not sent our enemies, the Poles, a host of soldiers in assistance and let his banners with the black eagle fly against Us in the field, and so retarded and obstructed the victory which God had given Us?' This was Gustavus Adolphus's most substantial complaint in 1629, and the act which he saw as evidence that the Emperor must be stopped, or 'we will all be sent to America to boil sugar'. From Vienna's perspective, it was not essential to lend a few regiments to troubled friends in Poland to assist against the Swedes, and the Emperor might easily have kept his troops at home. In short, the scale and duration of the war depended on a very large number of decisions against peace and many of these hung in the balance.

It may simply be a coincidence that so many of these decisions came down on the side of war. Improbable things happen. However, for some stages of the war, I think the infamous ability to let the war nourish itself created a bias in decision-making. Lack of resources is a major reason why people opt for peace, and this time was different. When armies lived partly from direct extraction, partly by accumulating debt to the soldiery and only partly from pay, then it became more difficult to stop than to carry on. This mechanism is not unique to the Thirty Years War, but this conflict seems to have been at a 'sweet spot' for this kind of warfare. The armies were sufficiently organized so they could live like this without disintegration. They were also sufficiently strong to intimidate and enforce, but they were not so large that they could not move around and sustain themselves from new resources for years on end.

This argument does of course touch on the next monstrously broad sub-question, on actors and structure. I am not sure there is a 'current thinking' on the issue. There is a variety of viewpoints, perhaps because there are at least three different kinds of structure in history. One is material structure. The geography so dear to the Annales historians, but also man-made objects. The material world circumscribes what is possible or reasonable to do and so creates a measure of homogeneity and stability. We tend to treat material structure as background, not really a part of history. Another is the kind of structure we speak about in terms like culture, practice, groups. Cultural structure consists of repetition and imitation, creating similarities in time and between people. It is a statistical phenomenon, however. People repeat themselves, but sometimes they don't; they learn from others, but less well than parents, preachers and teachers desire. Stability and homogeneity are not immutability and regimentation. This is easily seen in many studies from the social sciences. When these seek to measure the strength of statistical regularity, it is always rather low. Economists find that individual consumers or producers do not obey the 'laws' of the market well. Market forces are still important on the average, in the long term, because they do act with some strength on most actors and the aberrations average out, but they do not offer a precise description or exact forecast. The same can be seen in studies of culture. A third kind of historical structure 
is organizational, as exemplified by armies, states, churches, workplaces, households. Organization creates roles where different people tend to behave in the same way. Persuading them to do so is a goal in the case of subordinates and subjects. But organization also creates roles where individual variation is magnified into social importance, affecting commanders, communicators, even ordinary people who happen to be in a crucial place at a crucial time. Organizational structure can be used to enforce cultural regularity, but it also creates a platform for massive disruption.

In other words, the relationship between structure and actor resembles the relationship between the weather forecast and the weather. It is legitimate to extract the element of regularity from an essentially chaotic process, and it may be a very true description on a certain level of generalization, but a truthful sunny forecast does not preclude a little shower on your picnic. The Thirty Years War, like any conflict, consisted of organized attempts to influence what others did and, especially, to disrupt them in the case of the enemy. Innumerable individual decisions were magnified in importance by the organization of war. The impact on others made their acts, thoughts and fates less regular and predictable, and so less structured. In this way, the Thirty Years War demonstrates how different kinds of structure in history may impact negatively on each other, and studying large and complex slices of history like this conflict is necessary for understanding the interaction between different kinds of structural regularity.

Rizzo: Several aspects of the Thirty Years War seem to suggest that this conflict was not inevitable. To begin with, on the eve of its outbreak, most contemporaries were neither expecting nor preparing for a conflict, and definitely not one of such scale and duration. Then, an escalation began, leading to what has been termed the 'rapid internationalization' of the fighting. The very concept of escalation, in itself valuable to build a dynamic explanation of strategic events, can be misleading if misunderstood, insinuating that every further step is practically inescapable. Clearly, a certain degree of structural constraint cannot be denied and the burden of the past was real, but still, those steps were more often than not the result also of subjective attitudes, feelings, views, biases and choices, and as such they can hardly be deemed inevitable. Reciprocal mistrust, sense of encirclement, fear of isolation, brinkmanship, uncertainty and lack of accurate and reliable information, misperception and misjudgement under pressure (all typically stemming from individual perception and decision-making) - accumulatively contributed to the escalation of the conflict, not infrequently taking actors far beyond their initial intentions and plans. Furthermore, it has been underlined that after 1628, for a couple of years a coincidence of factors almost merged European conflicts into a common 'Armageddon', significantly emphasizing the relevance of seven momentous sieges (La Rochelle, Danzig, Stralsund, Magdeburg, Casale, Mantua, 's-Hertogenbosch). Ultimately, that did not happen, while conversely it is noteworthy that peace between the Empire and Sweden remained possible until 1636, even if it did not materialize.

'Inevitability' is often, if not always, a tricky tool to handle for historians and social scientists, not least because it can fairly easily slip into determinism of some kind, strong forms of path dependence, overestimation of causal chains (such as post hoc ergo propter hoc) and the like, inducing scholars to overlook the role of contingency and the potential for individual agents to actively participate in historical processes and influence their 
outcomes. We should also pay attention to the ambivalence of hindsight, which is both helpful and deceptive. Thanks to it, on the one hand, we can count on an increased stock of knowledge, which also fosters our ability to make comparisons. On the other hand, it might lead us to overrate necessity and structural constraints, together with 'strong' attributes of agency such as rationality, awareness or planning, while neglecting chance, latent functions or unintended consequences. In other words, when 'we now know' we can fruitfully rethink history, but we also run the risk of adopting a skewed perspective, failing to grasp what contemporaries really knew, felt and perceived. With ill-conceived hindsight, a given historical situation may seem to be a foregone conclusion, rather than the result of a multifaceted and uncertain process.

Not surprisingly, from Thucydides to Karl Marx and Alexis de Tocqueville, from Fernand Braudel and Antonio Manuel Hespanha to Paul Kennedy, John Lewis Gaddis, Geoffrey Parker and beyond, the intriguing relationship between agency and structure has often been intensely scrutinized by historians. Provided we are well aware that the field of sociology is largely different from that of history, we might also draw on Anthony Giddens's theory of structuration, one attempt among others to move beyond the dualism of structure and agency, and instead see them as mutually constitutive entities in constant interaction. Through the concept of 'duality of structure', Giddens shows how the interaction has both constraints and enabling qualities. When it comes to agency and structure, in most cases an et ... et rather than an aut ... aut approach is more balanced and more productive, even for historians.

\section{How far was the Thirty Years War an 'international' war, and how far should it be regarded as a milestone in the development of the inter- national system?}

Kampmann: The answer depends on what we exactly mean by international war. In one sense, the Thirty Years War was an international conflict from the beginning in that foreign powers were directly involved militarily. Nevertheless, in these early years of the war it would not have been impossible for the main actors within the Empire to make peace, suggesting that the conflict was not yet fully 'international' in the 1620s. For example, if the Emperor had offered the Protestant Estates peace terms after the Lower Saxon/Danish War (1625-1629) similar to those he later agreed at Prague in 1635 , the war could well have come to a definitive end. Of course, I know this is a counterfactual argument: the Emperor was prepared for such compromising peace terms only after the traumatic experience of the years 1631 to 1634.

Nonetheless, the Treaty of Prague shows that even confessionally or constitutionally firm and unbending princes like Ferdinand II or Maximilian of Bavaria could bring themselves to accept peace under such conditions.

After the late 1620s, the war became irreversibly international. The German protagonists could not finish it even if they tried. Furthermore, the Peace of Prague, which was praised as a sort of 'national' peace in 'patriotic' propaganda, was not in fact a 'national', Empire-focused peace. In practice, the Emperor had to rely massively on Spanish support to achieve this treaty, while the exclusion of both France and Sweden from the treaty doomed it. Only after ten more years and the loss of three armies, did the Emperor finally accept the international character of the war and open formal peace talks with both his international enemies. 
Concerning the war's national/international character, I would point out two other aspects. First, all armies, including those of the foreign powers, consisted of a high and ever-growing proportion of German soldiers. Secondly, the lines of the opposing international alliances were not closed. For example, the Dutch Republic (being a French ally) made war against Spain, but never declared or made war against the Emperor (and vice versa). And France never declared war on the Emperor (only on Spain), and Sweden likewise did not fight Spain (only the Emperor).

The Thirty Years War can only be regarded as a milestone in the development of the international system in a limited sense. In contrast to a frequently expressed opinion, the war and its concluding Westphalian peace did not bring about the notion of equality among the sovereigns (Louis XIV regarded himself superior to almost any other Christian monarch!) nor did it end the religious wars in Europe (only in the Empire). The peace did not produce a European (let alone global) 'Westphalian System' after 1648. Nevertheless, the conflict marked a turning point with respect to two important aspects of international politics: it demonstrated the extremely destructive and uncontrollable dynamics of war in an unprecedented manner, while the manner of its conclusion indicated clearly that multilateral peace congresses could be successful. Not many diplomats and politicians had believed that before the Thirty Years War.

Rizzo: From my perspective, that is, the perspective of an Italian historian focused on the Spanish Empire, the Thirty Years War looks like an 'international' war for a series of reasons, the most obvious of which is the increasingly important foreign involvement. While underscoring that the conflict originally stemmed from mainly German and Central European causes, recent compelling studies show that both sides called on external aid, triggering a 'scramble for support' with the intervention of several great and medium-sized powers on multiple fronts. On a much smaller scale and with much less dramatic consequences, a somewhat similar dynamic had already emerged during the Cologne War (1583-1588): deeply concerned about the security of the Spanish Road, Philip II sent troops to aid local Catholics, thus increasing foreign influence on Imperial politics - even more so, since the Dutch gave support to the rival party. Significantly enough, though, both powers practised self-restraint, since neither Spain nor the Netherlands aspired to continuous interference in German affairs.

This is not to say, however, that every conflict that occurred across Europe between 1618 and 1648 is to be embedded in and totally absorbed within the Thirty Years War, nor that the undeniable need to connect the latter to a broader strategic picture implies that it was merely a part of a 'global' struggle for hegemony in Europe. In this sense, I believe the Thirty Years War differs to some extent from the Italian Wars (14941559), which obviously had regional elements but were overwhelmingly influenced by the clash for European pre-eminence. Make no mistake: such a struggle indeed existed, just as global forces and phenomena are to be taken into account; those conflicts intertwined, overlapped and influenced one another in various ways; the events on a given front could heavily affect the developments on others, all the more so since some belligerents were simultaneously engaged in different regions. But those wars began as distinct conflicts and remained as such, to a large extent.

Revealingly, even the strategic collaboration between the Spanish and Austrian Habsburgs was as vital as it was limited, and far from comprehensive: the two branches 
shared a number of rationales, goals and means, but did not always agree, nor did their strategies necessarily coincide.

As an economic historian, I would add that the Thirty Years War was international also in terms of human capital and manpower. Within the framework of the 'business of war' and the so-called internazionale aristocratica delle armi (international military aristocracy), thousands of officers as well as rank and file from several nationalities circulated throughout Europe to serve - just think about Italians and Scots. Last but not least, I would mention a 'biological' factor. Troop movements and the influx of soldiers from abroad favoured the spread of infectious diseases, with remarkable demographic, socio-economic and moral consequences such as the plague that scourged Northern Italy in 1630/31, powerfully narrated in Alessandro Manzoni's celebrated novel The Betrothed (1827).

As regards the implications for the history of international relations, although the 'classic' interpretation of Westphalia as the defining moment for the birth of the modern international order based on Weberian sovereign states is perhaps a bit timeworn, even among political scientists, we should not underestimate the importance of the treaties as a crucial step along the winding way towards a new system. In the wake of a shocking, unprecedented bloodbath, thanks to an approach resting on at least partially innovative principles and methods, at the end of the day diplomacy succeeded in providing a critical framework for peace, moderation and stability in the heart of Europe, one which significantly has gone down in history as a model for future settlements.

Besides, provided we do not oversimplify complex historical processes, nor think in terms of abrupt strategic rises and falls, it is fair to say that the war and the peace facilitated important changes in the European balance of power. Inter alia, as the Empire's heyday had passed, the Austrian Habsburgs progressively gained ground and got the upper hand over the Spanish branch (though the battle of Rocroi should definitely not be seen as the end of Spanish pre-eminence) — even in Italy, where Spain's interference in the long-standing issue of Imperial fiefs seems to have faded away. Far from being a full-fledged absolutist and 'modern' state, France nonetheless strengthened its international standing and strategic influence and, most importantly for France and the Protestant powers, the nightmare of Catholic Habsburg hegemony in Europe had finally been removed.

Haude: The Thirty Years War had a number of 'international dimensions'. Still, while it took place within a broader context of conflicts in Europe, these had their own respective agendas. As has been well established, the Thirty Years War was fought for a number of reasons, of which constitutional and dynastic issues rank among the most important, with religion an inseparable part of the mixture. Nevertheless, the involvement of many other European powers in the conflict points to concerns that transcend these internal issues. The political (if not always religious) alignment of European countries and dynasties drew supporters from around the Continent into the war, and there is ample evidence of fear over the Habsburg's growing power.

This debate over the war's wider political significance remains in flux, with the most intriguing thesis that advanced by Johannes Burkhardt. For him, the war represented a Staatsbildungskreig rather than a Staatenkrieg (a war about how a state is constituted rather than a war between states), but he also underscored the European dimension 
of this conflict. In his interpretation, the war was fought over who would rule Europe. Eventually the French, Habsburg and Swedish visions of empire, in which each power aspired to rule supreme over Europe, gave way to the compromise of a 'summitless pyramid', with a number of powers existing 'side by side with equal entitlement'. Alongside the constitutional formation of the Holy Roman Empire, Burkhardt placed concerns pertaining to the political order of Europe as the underlying factors causing the war.

Just as the inevitability of the war has come under scrutiny and criticism, so has the assessment of its resolution in the Peace of Westphalia. Earlier scholarship evaluated the settlement in wholly negative terms, as reverting to antiquated patterns that perpetuated the Holy Roman Empire's political and religious fragmentation and arrested Germany's development, while nation states were blossoming elsewhere. More recently historians have demonstrated convincingly both the rearward- and forward-looking qualities of the treaties, and have assessed them much more positively. At a time when nation states have lost their cachet, Germany's political path now looks more like shrewd federalism than wrong-headed particularism. Moreover, scholars have highlighted the path-breaking legal dimensions of the Peace of Westphalia. In his article 'Der Westfälische Friede - Grundgesetz für Europa?' in the volume Der Westfälische Friede (1998), edited by Heinz Duchhardt, Heinhard Steiger attributes 'epochal significance' to the treaties 'because for the first time they had succeeded by means of modern international law in making peace between equal powers within Europe' and thus laid the 'foundations of the international law of treaties in the European order for the next 150 years'. Importantly, these did not preclude future wars but provided a legal framework by which conflicts could be conducted and resolved. The fact that up until the modern era the Peace of Westphalia served as the essential legal blueprint for international conflict resolution makes it a milestone in the international system.

Lind: 'International' is an anachronistic term, as the quotation marks in the question already hint. It is equally anachronistic to call the Thirty Years War a 'German civil war', although the latter at least assumes a clear division between international and national. Still, I would not hesitate to call the Thirty Years War an international war for reasons of language as well as substance. Using anachronistic terminology can never be off-limits on principle, but it may deserve some explanation, like obsolete terms generally do. The use of any word is an act of categorization, joining things which are never absolutely identical.

Explanations and definitions are certainly necessary, but of course there is a point when lumping together is no longer helpful. I do not find that 'international' in the context of the Thirty Years War is stretched too far, because the war has so much in common with other, later wars described as international, then and now. All the major European rulers concerned themselves with the war and most of them participated, at least by supporting friends. Furthermore, these major rulers were not that different as military and political actors from later heads of self-consciously sovereign states. It is true that this international character did not apply equally to all stages, theatres or actors of the war, but this is also the case with many major conflicts later on. We do not doubt the international character of the Napoleonic Wars or the Second World War because there were guerrillas or transnational ideological communities for instance. 
The era of the Thirty Years War was surely a milestone in the development of the classic states system. In the case I know best, the Danish state established a large permanent army, doubled the navy and set up permanent legations in all major states, even remote Spain. The tangled complexity of rule in the duchies of Schleswig and Holstein was reduced, and militant patriotism became the dominant discourse on war in print. In short, the Danish state approached the ideal-type European state much more than before, and many others did the same. All was motivated by war, and mostly by the Thirty Years War. In political science mythology it is of course the Westphalian peace which gives birth to the modern state system, but in my opinion that treaty mattered little compared with the influence of protracted war - even if the peace did move the Empire a bit closer to conformity with the conditions in the rest of Europe.

Tischer: The Thirty Years War was an international war from its very beginning because many of the protagonists from inside the Holy Roman Empire were at the same time international players. Frederick V of the Palatinate was when he married the daughter of the king of England, and the Bohemian estates, when they elected him as an anti-king, hoped that he would get support from his wide network of fellow believers and relatives. The Habsburg dynasty, with the future Emperor Ferdinand II, was international in itself. The Austrian Habsburgs possessed the crown of Hungary outside the Empire and were part of the broader House of Austria. The Habsburg kings of Spain were always actors in the Holy Roman Empire too, and when the Bohemian Revolt broke out, they supported their Austrian relatives. The Habsburg power politics and the religious conflict were of interest both inside and outside the Empire. Many Imperial estates traditionally pursued their own foreign policy, a practice which was confirmed with the Peace of Westphalia. Thus, it was no surprise that foreign powers were involved in the entangled Imperial conflicts which played a role in the Thirty Years War, in particular when we consider that powers like the Dutch States General or the king of Denmark occupied an intermediate position between foreign power and member of the Holy Roman Empire.

Most of the Imperial estates did not want to go to war against the Emperor, their overlord, but they nonetheless welcomed political support against an increasingly powerful House of Habsburg with its threat of a 'Spanish slavery'. In particular, the Protestant estates were put more and more on the defensive by Emperor Ferdinand II. Although they did not invite Sweden to help them, it was definitely a relief for the Protestant faith when King Gustavus Adolphus, who was related to several Protestant German princes, overran the Empire in 1630/31 and forced his fellow believers into an alliance. The intervention of Sweden, and later of its ally France, came in a moment when the struggle for the constitution and for the religious coexistence in the Empire was at a stalemate. Although there was a peace concluded in Prague without the foreign powers in 1635 , the situation was not really stable and there was no political consensus within the Empire to back the Emperor's calls to expel France and Sweden. Finally, these two powers became the main partners shaping the Peace of Westphalia.

The idea of the Peace of Westphalia was not to fix a new European system. Nevertheless, it rearranged the relations of some of the leading powers and created the basis for future development in Europe. Moreover, the peace congress in Münster and Osnabrück lasted approximately five years and attracted nearly all the European 
powers. Apart from England, which had descended into civil war, all Europe's Catholic and Protestant powers joined the congress permanently or at least for a short time. Thus, the diplomacy and the contact between them became an important model for future interaction. This makes the congress definitely a milestone in international history. By its mere form, the Peace of Westphalia was a treaty between France, Sweden and the Empire, a treaty that included, however, a reform of the Empire's constitution. The Holy Roman Empire preserved its international structure and thus became an international platform in Europe also for the future. This went further when the Imperial Diet became permanent after 1663.

\section{How have the cultural turn and the use of concepts such as 'experi- ence' transformed our understanding of the war?}

Haude: Cultural turns have had a significant impact on studies of the Thirty Years War. As in other fields, the linguistic turn has challenged the straightforward interpretation of texts, authors and events and promoted a more cautious and circumspect reading of sources and intentions. Moreover, in the wake of the cultural turns, many historians have embraced microhistory, historical anthropology and the history of everyday life, in which the focus is directed away from political and constitutional history and towards the social and cultural experiences of individuals and communities. Thus, war is analysed with regard to its effect on society. This redirection towards the war on the ground has also had an impact on military history, by looking beyond military strategies, logistics, battles, sieges and generals towards the everyday reality of soldiers and camp followers. Besides illuminating those aspects of history that traditional studies have largely left untouched, cultural turns have also afforded historians a range of lenses through which to look at history anew. The spatial turn, for example, with its emphasis on the social construction of space, has sensitized scholars to the importance and meaning of space in historical events and processes. Closely related to this area is the history of movement, exile and migration, which has stimulated novel perspectives on the war as well.

Cultural turns and the focus on 'experience' have added significantly to our understanding of the war. While traditional studies of the war's origins and motives, its demography and its political and military leaders have made vital contributions to our grasp of the conflict, their concern with a quite select layer of people and a rather panoramic perspective can offer only limited insights. The new focus on experience opens up the perspective on wider segments of the populace and illuminates the social setting of the war. One may ask whether 'experience' is indeed accessible to us. While early modern autobiographical accounts offer rich descriptions of the individual in his or her community and provide vivid reflections on perceived reality, these statements need to be read carefully with all the tools the linguistic turn can offer. The turns, however, also challenge historians to reflect on what 'reality' is and who defines it. The new approaches encourage openness to multiple realities, including the ones contemporaries perceived to be true. The fact that historians can establish there was method to the belligerents' aggression does not invalidate people's perceptions and experiences of seemingly unending misery on the ground. Nor were contemporaries' experiences the same across time and space. Connecting these manifold 'realities' will move us closer to understanding the war in its complexity. 
Rizzo: The cultural turn has offered new perspectives on the history of warfare, which is all the more important for the study of early modern European societies given the pervasive role that war and the military played during these centuries: experiencing war deeply affected the lives not only of the troops, but also of many civilians. Therefore, by investigating the way people perceived war and passed their experiences down to others, we can learn more about their identities, their values and beliefs, their views on the role of God in history and human life, their Weltanschaung, if you will. The Thirty Years War in particular, as a defining experience for many individuals and communities, has benefited from new research trends. Moving away from a somehow more traditional 'positivist' approach, these research lines no longer employ sources mainly as means to reconstruct 'objective facts' (or anything like that), but rather draw on them as a gateway to understanding how more or less traumatic experiences were lived through, remembered and conveyed to others, thus contributing to depicting individual and/or collective identities and behaviours.

That said, inspired by recent developments in source criticism (for example, by Yuval Noah Harari) and by my own research experience, I would underline that several interpretive and methodological issues need to be addressed in order to get the best out of a variety of historical sources expressing war experiences. The intricacies of the diverse forms of personal testimony have to be assessed, as well as the milieus, interests and motivations of their authors. It is a fact of life that even the most accurate and unbiased report of a certain event is the result of subjective perception, influenced, for example, by the cultural background of the author. In addition, more or less wittingly and bluntly, a report (such as a memoir) is usually something of a means to an end, be it self-promotion or self-defence, political or religious propaganda, the spread of the writer's views and opinions, etc. etc. In fact, the very selection of the events to be narrated and commented upon may be meaningful. Moreover, we have to ask how far individual experiences are typical of wider communities, and we should never forget that literate and educated people are over-represented among authors of these texts. As far as possible, both the contents and the style of the source should be analysed, for instance searching for topoi, clichés and passages copied from other literary texts or media. In this respect, the fact that many such sources do not merely and straightforwardly record what individuals had experienced raises challenging questions about their credibility. The question, then, is not only: How far can we trust the source in order to reconstruct 'actual' historical reality (assuming it exists at all)? but also: To what degree is the source authentically autobiographical, that is to say, a 'genuine' expression of the author's experience and identity? How deep and distorting is the intrusion of other 'external' factors?

Kampmann: Our understanding of the Thirty Years War has changed fundamentally in the last decades, and in my view, the cultural turn, and especially the new perspective called the 'cultural history of politics' (Kulturgeschichte des Politischen), has influenced this transformation to a large extent by abandoning traditional master narratives. But this process had begun long before all cultural turn(s). The first important step was the departure from the traditional, basically national master narrative of the Thirty Years War, which shaped the common understanding of the war from the nineteenth until the second half of the twentieth century. This narrative saw the war 
basically as an outcome of the steady decay and ongoing fragmentation of the Holy Roman Empire, in contrast to its centralized absolutist neighbour states. This negative image of the Empire has been abandoned since the 1960s. Today, no serious historian would maintain that the Holy Roman Empire and its structure as such was responsible for the war, but rather that the war was rooted in the Empire's temporary dysfunction around 1600. Rather than constituting a national catastrophe, the survival of the decentralized Empire is now regarded generally as a positive development.

However, other traditional narratives persisted until more recently, when they were abandoned under the influence of the cultural turn and through a closer look at the semantics of politics and at the leading principles of historical actors and through more critical attention to metahistorical preconceptions. One of these traditional claims was that the war should be regarded as the result of blind religious hatred and fundamentalist confrontation, and that, consequently, the experience of the conflict contributed to ending the confessional age. This is an interpretation which assigns the Thirty Years War a special place in the genesis of enlightened European statehood. Recent research suggests that this picture is misleading. Religious extremism did not gain decisive influence on political decision making, but we cannot speak of secularized politics before or even after 1648. Instead it was one of the merits of Westphalia to ban religious violence in the Empire despite enshrining continuing confessional diversity.

The use of new concepts like 'experience' has contributed to the abandonment or at least modification of traditional historiographical narratives. In the older historical writing, there was a tendency to differentiate between the active military or political elites and the passive, purely suffering population. Put simply: a contrast between 'decision makers' (whose decisions were meticulously reconstructed) and the victimized ordinary population. In my view, there is a clear tendency within current research to overcome this simplistic dichotomy. In more recent historiography the common civil and military population is seen and interpreted as an actor in its own right. Research in this field is interested in the common experience of the war and the reaction to military violence, in the (sometimes, but by no means always, hostile) coexistence of the military and the civil population, in economic actions, in ways of popular communication, the role of the public etc.

Lind: The new approaches have added to perspectives, rather than transformed them, I would say. The history of battles and treaties has not changed much, if at all, but in a general history of the war those aspects would be squeezed compared with one written fifty or one hundred years ago. One may add that our perception of the Thirty Years War may have changed less than that of many other wars. Due to the religious aspect and the importance of the interaction between soldiers and civilians, issues of culture and of war experience have been a prominent part of the history of the Thirty Years War from the beginning. Grimmelhausen's autobiographical novel of his war experiences, Simplicissimus, has been almost continuously in print since the seventeenth century. The cultural turn has thus turned the Thirty Years War into a more interesting piece of history than before, especially outside Germany. Seen from that point of view, the war is immensely relevant now - even for those who have not yet realized how relevant its political and military aspects are for understanding much contemporary warfare. 
Tischer: For our understanding of the Thirty Years War it is important to recognize that this was not just a clash of contrary religious beliefs or political concepts. The world around 1600 with its views, everyday life, expectations or mentality was very different from ours. The use of force and violence was quite usual, even in daily life, and war was more or less accepted as normal. Moreover, religion was taken extremely seriously and none of the actors had a secular concept of the world. Therefore, a historian of the war should have an extended ethnological and anthropological view of what happened. Although the Thirty Years War is part of a long-term development of the Holy Roman Empire and of international law, I find it extremely helpful to take a look at various aspects of the society from which the war emanated. Conflicts were fought out not just through military actions and diplomatic negotiations, but also through cultural representations. A Catholic procession in a Protestant environment like that in the city of Donauwörth in 1606 could stir up emotions more than an exchange of legal opinions which later historians might find easier to analyse because of their rational content. At the Congress of Westphalia, the quarrel over ceremonial rank was sometimes more severe and more difficult to resolve than claims for further territory - not because the diplomats and politicians were attached to vanities, but because the ceremonies represented the political order. When we want to understand the war, we have to understand the complete political, social and symbolic order, the view of the world and its perception.

It is remarkable, however, that a broader and more cultural view of the war underlines much more than the differences between the early modern and the current world. There are issues which have been underestimated that show also the modernity of the early modern period. Thus, the Thirty Years War was the first major conflict in which print media played a significant role. Episodes like the one hundredth anniversary of the Reformation in 1617 or the horrible result of the siege of Magdeburg in 1631, when most of the citizens lost their lives, became media events that made a wider public accepting of war. Moreover, the cultural view gives an idea of the role of anthropological aspects in political history.

Cultural misunderstandings and psychological factors are crucial for every communication process. Thus, we understand much better the confrontation between France and the Habsburgs, for example, when we see their opposing political concepts and their failure of understanding in the context of their different cultural backgrounds, traditional perceptions and mutual fear. We don't even need to look at more complex cultural aspects, because all and every kind of linguistic confusion can produce serious effects which have only been analysed since the cultural turn. Thus today we recognize fundamental differences in mentality, religion, views, society or language between France and Germany, or even between northern Germany and the south. Such differences intensify conflicts or even produce them, and it is evident that they did so also in the Thirty Years War, at a time when they were much more emphasized and when few people were open-minded or flexible in their views and practices.

\section{What work needs still to be done and how best should that research be undertaken?}

Haude: The emphasis on experience has enriched our understanding of life, society and the military during the Thirty Years War and has shown not only commonalities, but also differences in how contemporaries encountered the war and its repercussions. 
Further regional studies will help us gain a more nuanced picture that pays attention to local conditions and how these affected people's experiences of the war. This can best be accomplished by exploring materials in regional archives.

Furthermore, the war has been studied almost entirely with an eye towards its warring religious, dynastic and political groups. The description of tremendous damage was briefly challenged by S. H. Steinberg, who in the mid-twentieth century asserted that the war was not as ruinous as historians had claimed. Today, with a host of local studies to buttress the more general conclusions, the devastating, if varied, effect of the war is an irrefutable fact. And yet the narrative of destruction is so dominant that it has left almost no room for other aspects of the war. Admittedly, we know that more remote places suffered less than those along the path of troop movements, but what about areas that lay in the thick of military occupation?

Ever more studies of early modern Europe are drawing attention to impetus for coexistence and co-operation during the age of Reformation, which is otherwise known for its religious, political and social conflict. For the Holy Roman Empire, scholars have focused particularly on cities and territories, where different confessions existed and where these communities had to find ways to live together. The Thirty Years War has barely been considered in this regard - maybe because it stands as the conflict par excellence. This horrendous war, however, has more to offer than tales of conflict. Peter Wilson has emphasized that, alongside fighting, negotiations for peace continued throughout the war. Matters of practicality, too, induced co-operation and coexistence between people of different faiths and political parties. Moreover, the continuous movement of people brought together individuals and groups of diverse confessions not only in select locales, such as Augsburg, but also in countless places throughout the Empire, and this affords a particularly instructive perspective on issues of coexistence in a confessionally divided society.

While the devastation during the war was real, extensive and often overwhelming, situations were often more complex than the traditional master narrative allows. Notably, besides narratives of the misery, contemporaries' autobiographical accounts also provide glimpses of the encounter with people from other countries, faiths and cultures, and relate the results of such meetings. Sometimes their words reflect mystery, impatience and confusion; at other times, they manifest curiosity and an eagerness to 'pick the other's brain'. Importantly, these meetings did not always end in death and destruction, but every so often in remarkable shows of concern and care for others.

Kampmann: One of the most durable legacies (or rather 'burdens') of the older national historiography is the concentration on the first half of the war, before 1635, with its defining 'heroic' or 'tragic' figures like Gustavus Adolphus und Wallenstein. Even more recent general surveys continue to stress these years disproportionally. Such a view is actually untenable historically, since these later years were of course decisive for the outcome of the war: just imagine what neglecting the period after 1916 would mean for our historical image of World War I, or of the years after 1943 for that of World War II. Moreover, the concept that 1648 has to be regarded as a total historical break, as a 'zero hour', has been questioned for good reasons. On the contrary, many political, diplomatic, military, economic and constitutional developments of the later seventeenth and eighteenth centuries have their roots in the second half of the Thirty 
Years War. For example, the Franco-Bavarian alliance which profoundly shaped the history of the later Holy Roman Empire had its precursor in the close political cooperation between these two partners in the 1640s. The same is true for the growing mistrust between the Dutch Republic and France. Or if we look at military developments, we can already see indications that the foundation of several standing armies of the later seventeenth century was laid in the 1630s and 1640s. We can observe similar developments with respect to the economy or to demography with, for example, Hamburg's rise as a dynamic, commercial city beginning in the second half of the Thirty Years War. Finally, similar connections can be drawn for constitutional and judicial developments, with signs that 1648 did not mark a clear break in the work of the Imperial law courts. All these connections indicate the importance of further work on the war's later years. The preconditions for this are now much better than they have ever been. Critical editions of sources previously focused on the earlier decades of the war, but things are improving with the impressive progress of editions like the Acta Pacis Westphalicae (moreover now accessible in digital format).

In my opinion, there is another area of future research which points beyond the war to examine seventeenth- and eighteenth-century conflict and peacemaking comparatively. We know much about military structures, as well as negotiating and peacemaking methods during the Thirty Years War, but it would be extremely useful to compare these aspects both before 1618 and after 1648 with those during the war itself. For example, the Westphalian Congress is one of the best investigated peace processes, but earlier and later peace congresses desperately need further research, and in many cases, there are not even critical editions of the treaties they generated. This in turn would help provide innovative comprehensive explanations of the onset, course and consequences of the war to fill the gap left since the older national master narratives were abandoned.

Lind: I am sure the most important work to come will not be what we desire but what surprises us. However, I would like to learn more about the Thirty Years War as a Europeanizing process. We know something about the 'military diaspora' moving people and influences during the war, but a lot less about the numerous other migrants and displaced persons. Organized military movement did also increase in geographical range. Denmark saw the first army from outside the Scandinavian-Baltic area since 974, during the reign of Emperor Otto, and the first ever foreign fleet. All this exemplifies how large-scale European political interaction was becoming much more important. The war years saw a massive increase in printed news, including the first regular newspapers, nourished by these interesting times. Battling with others is perhaps not the best way to achieve European integration, but it creates a kind of community.

Tischer: First of all, we still know very little about the postwar generations. Since World War II we have realized that a big war leaves traces on those who survive and even on their children and grandchildren. Such traces can be found in the politics of the late 1640s and of the 1650s, when many politicians were extremely nervous about security and how to stabilize the Peace of Westphalia. This might have made them unable to recognize new constellations and to react properly, but the shared anxiety helped overcome religious differences, at least in politics. There are solid detailed studies on some of the political events after the Peace of Westphalia, for example on the 
Execution Diet by Antje Oschmann, on the Imperial Diet of 1653/54 by Andreas Müller, and on the next long-term assembly, the Deputation Diet of 1655-1663, by Matthias Schnettger, but there is still no overview of the political history of the postwar Empire as such, not to mention a study on the society of this time, which admittedly would be much more difficult to write. I think that a closer look at the first postwar decades and more specifically at how people at that time regarded the war would improve our understanding of subsequent German history, of the consequences of this war and of big wars in general. The Thirty Years War left traces not only in politics, in the constitution and in institutions, but also in art, literature, mentality and the development of the population. Benigna von Krusenstjern and Hans Medick organized a conference the proceedings of which were published in 1999 and give a good idea how such a new approach to the war and its aftermath could be implemented. Such an approach should be interdisciplinary and include a wide range of sources, such as legal records or personal testimonies, which have not yet been analysed in the context of the war. I hope that one day we will see a history of postwar Germany or Europe that helps to understand better how the Thirty Years War influenced this future development.

I think, however, that besides a renewed history of postwar Germany we also need one for prewar society. The war's violence is usually linked to the military system during the conflict, but we should not underestimate the importance of broader social characteristics. I am currently reading the diary of Wolfgang Ammon, a Franconian pastor who wrote an account of his life before and during the war and was eventually killed when the Imperial army conquered his hometown. This document of ordinary life in the German countryside gives an idea of just how harsh life was even before the war. Violence, hunger and misery were always a part of it. We should ask what the war meant for this society and how far this violent, non-secular society underpinned the war's outbreak.

There is, however, a lot of further work to do. One important task is to synthesize the large number of different regional and single-case studies. In their important recent monographs, Christoph Kampmann and Peter Wilson rightly put the focus on the long-missing European perspective and stimulated fresh discussion. This does not mean, however, that the history of the Thirty Years War as a German conflict has come to an end. Existing research reflects the situation of Germany with its multitude of territories and regions and it is still a challenge to bring the various results together.

Rizzo: Given the extreme complexity of the Thirty Years War, its far-reaching implications and outstanding importance within German and European history, it is not surprising that a great deal of research has already been undertaken, but much remains to be done in various fields. Since the other colleagues participating in the panel are far more competent than I am about this Forum's German 'core business', I will not attempt a comprehensive wish list, so to speak, but instead I will focus briefly on current historiography concerning Italy and the war, before sketching a desirable scenario for a set of studies to be undertaken in the near future, with specific regard to research topics that are of particular interest to me.

Although the Italian Peninsula can hardly be labelled the main battleground of the Thirty Years War, according to Gregory Hanlon the latter was the most important event in Italian history between the Council of Trent and the French Revolution, and it 
deserves a lot more attention than has been devoted so far. It must be said, actually, that in recent years a few scholars have at least begun to fill the gap: I refer, in particular, to Davide Maffi's seminal monograph on Spanish Lombardy and Gregory Hanlon's trailblazing studies on the Duchy of Parma. Taking the cue from such works, as well as from a much wider international bibliography, other Italian territories should be investigated in depth, starting from a thorough survey of local archives and libraries in search of brand-new or at least still-unexplored primary sources (significantly enough, for example, the spark for Hanlon's monograph on Parma in the fateful biennium 16351637 was provided when he came across unparalleled company rosters in the Archivio di Stato di Parma). Building on this documentary evidence, a wide range of research issues should be addressed with a coherent and multifactorial approach. For instance, diplomacy and broader international strategic developments should be connected to logistics and troop movements in the Peninsula, and to their hefty implications for local communities in terms of demographic, socio-economic and political disruption, whilst not forgetting that they also brought a vast array of economic and financial opportunities for both soldiers and civilians. Moreover, the resilience of the localities struck by war also deserves attention. The recruitment of troops, together with their circulation across the Peninsula and the Continent, is another key subject, all the more so since it could stimulate co-operation among scholars from different countries working on different war fronts. Clearly, these are only a few themes among a great many more which should be explored sooner rather than later. When it comes to historical research about Italy and the Thirty Years War, the best is (hopefully) yet to come.

Keywords: Thirty Years War, Peace of Westphalia, war, violence, diplomacy, Holy Roman Empire 